\title{
ЗАСОБИ ВИРАЖЕННЯ НЕГАТИВНИХ ЕМОЦІЙ ПІД ЧАС СВАРКИ В УКРАЇНСЬКІЙ, РОСІЙСЬКІЙ, АНГЛІЙСЬКІЙ ЛІНГВОКУЛЬТУРАХ (на матеріалі творів \\ І. Нечуй-Левицького, М. Гоголя, Ч. Діккенса) \\ ВІРА СЛІПЕЦЬКА \\ Дрогобицький державний педагогічний університет імені Івана Франка, Дрогобич - Україна vslipetska@ukr.net
}

SPOSOBY WYRAŻANIA NEGATYWNYCH EMOCJI PODCZAS KŁÓTNI W UKRAIŃSKIEJ, ROSYJSKIEJ, ANGIELSKIEJ LINGWISTYCE KULTUROWEJ (na materiale utworów I. Neczuja-Lewyckiego, M. Gogola, Ch. Dickensa)

\section{WIRA SLIPECKA}

Państwowy Uniwersytet Pedagogiczny imienia Iwana Franki w Drohobyczu, Drohobycz — Ukraina

STRESZCZENIE. W artykule przeanalizowano narzędzia językowe neutralizujące negatywną energię, wygenerowaną przez negatywne emocje wskutek negatywnego postrzegania i oceny rzeczywistości w trakcie kłótni i sporów, które funkcjonują w świadomości językowej człowieka w ukraińskiej, rosyjskiej, angielskiej lingwokulturologii. Do takich zasobów językowych zaliczyć można przekleństwa, osądy, komunikaty niewerbalne.

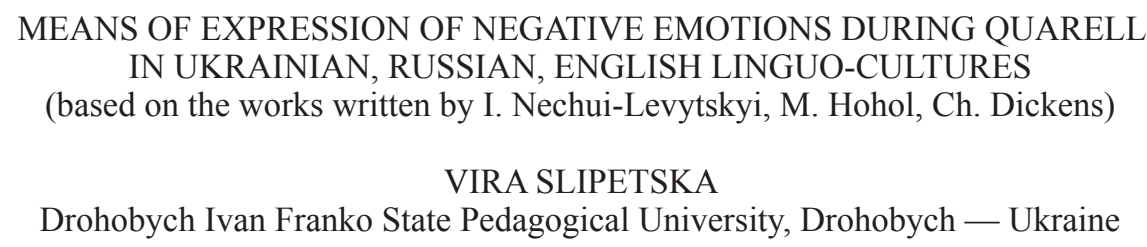

ABSTRACT. The article focuses on the analysis of language means of liquidation of a negative energy caused by the negative emotions and estimation of the reality that function in a personality's language consciousness in Russian, Ukrainian, English linguo-cultures. The curse-words, evaluation-words and non-verbal means belong to these language means.

ринцип антропоцентризму дедалі виразніше виявляється в гуманітарних науках, передусім у мовознавстві, що пов'язано й з виявленими культурологічними чинниками, які активізували в останні роки популярність лінгвокультурологічних досліджень, зокрема й у ракурсі проблем міжкультурної комунікації. Діяльність людини, як відомо, не відображається, а переломлюється в іiі свідомості, спроможної до різних змін, зумовлених складною людською сутністю. Мовна особистість як суб'єкт мовної діяльності не лише дає об'єктивну інформацію про довкілля, а й виражає суб'єктивне ставлення до навколишнього світу - виражає почуття, емоції, оцінку, що яскраво репрезентується передусім у комунікативному просторі, просторі художнього тексту. 
На сучасному етапі розвитку лінгвістики вивчення засобів вираження емоцій і їхньої оцінки посідає особливе місце. Така зацікавленість пояснюється передусім тим, що емоції й оцінка як універсальні філософські, лінгвістичні й психологічні категорії $є$ основними компонентами процесу комунікації. В останній час у міжособистісних, інтерактивних стосунках простежуємо вияв неабиякої агресії. Необхідно, як видається, активізувати мовні засоби, що допоможуть $\dddot{11}$ нейтралізувати, а для цього варто звернутися до ментального досвіду наших предків.

Упродовж останнього десятиріччя вийшло друком чимало наукових досліджень, присвячених визначенню поняття оцінки як філософської, так і лінгвістичної категорії, процесу іiі лексикалізації і граматикалізації (Н. Арутюнова, О. Вольф, Т. Космеда), проблемі співвідношення оцінки та емоцій (В. Шаховський, В. Вілюнас, О. Філімонова, А. Яновець), вивченню співвідношення категорії оцінки та категорії модальності (Ф. Бацевич, О. Вауліна, А. Загнітко, Т. Ніколаєва), виявленню особливостей лексичного вираження оцінки (Л. Бабенко, Т. Космеда, О. М'ягкова, О. Островська), ії граматичної репрезентації (Т. Булигіна, О. Дибовський, В. Жура, Т. Космеда, Л. Мацько, Д. Рязанцева, О. Халіман), своєрідного вияву в МКС, концептосфері різних мов (Е. Гетте, А. Вежбицька, О. Винарська, О. Димитрова, М. Красавський, А. Приходько, З. Фоміна), художньому тексті (В. Болотов, І. Бидіна, П. Волкова, С. Гладьо, Я. Покровська), комунікативному просторі загалом (Ф. Бацевич, А. Загнітко, Т. Космеда, К. Сєдов, Й. Стернін, Т. Осіпова, І. Шкіцька), зокрема й з огляду на категорію гендеру (Г. Богданович, О. Горошко, Л. Синельникова, Л. Саліонович) і т. д.

Традиційно мовознавці визначають категорію оцінки як позитивну чи негативну кваліфікацію предмета (М. Брандес), що передусім пов'язано з відповідними емоціями. Незважаючи на значну кількість праць, присвячених дослідженню категорії оцінки, у вітчизняній лінгвістиці потребують комплексного вивчення засоби вираження оцінки, передусім емоційної, в художньому тексті зокрема, з огляду на специфіку ментальності того чи того народу. Актуальним у цьому ракурсі є це дослідження.

Мета статті - схарактеризувати засоби вираження негативних емоцій як наслідку негативної оцінки довкілля під час сварки, що властиві українській, російській, англійській ментальності.

Об'єкт дослідження - негативні емоції та їхня оцінка під час сварки чи певної суперечки в художніх текстах I. Нечуй-Левицького, Миколи Гоголя, Ч. Діккенса.

Предмет дослідження - прокляття як найбільш поширені й типові засоби вираження негативних емоцій і їхня оцінка в українській, російській, англійській лінгвокультурах; слова-оцінки; невербальні засоби (підвищення тону голосу).

Матеріалом дослідження слугують художні твори І. Нечуй-Левицького Кайдашева сім'я, Миколи Гоголя Как поссорились Иван Иваныч с Иваном Никифоровичем, Ч. Діккенса Записки Піквікського клубу.

На думку Г. Богданович, культура - це „сукупність людських способів діяльності і її наслідку, що знаходиться у багатовекторній залежності від мови, визначається нею і впливає на неї"'. Мова не тільки відображає культуру, але і є іiі складником. Цей взаємозв'язок уперше й найбільш виразно, як відомо, відображено в працях В. фон Гумбольдта. На його думку, „різні мови - це не

\footnotetext{
${ }^{1}$ Г. Ю. Богданович, Русский язык в аспекте лингвокультурологии, Симферополь 2002 ,
} 
різні позначення одного й того ж предмета, а різні бачення його"2. Концепція В. фон Гумбольдта отримала подальший розвиток у працях Ш. Баллі ${ }^{3}$, О. Потебні ${ }^{4}$, В. Маслової5 , В. Карасика ${ }^{6}$ та ін. учених.

Г. Богданович дає визначення явища лінгвокультурологізму „як тісного зв'язку мови й культури народу, розуміння розвитку мови як наслідку творчої діяльності людини" ${ }^{7}$.

Одним з базових положень лінгвокультурології $є$ інтерпретація мовних фактів 3 позицій ментальної лінгвістики ${ }^{8}$. Усталеною в мовознавстві $\epsilon$ й думка, що важливим культурологічним джерелом є паремії як найбільш послідовні мовні репрезентанти культурних уявлень народу.

Зауважимо також, що однією з яскраво виражених рис національного характеру українців $\epsilon$ кардіоцентризм, що виявляється в їхній надмірній емоційності. Можливо, меншою мірою, іншими способами вираження, але ця риса характеризує й національний характер російського народу. Емоції зазвичай репрезентуються у вигляді мовних засобів вираження позитивної чи негативної оцінки, що, безперечно, фіксується на відповідній шкалі оцінки9.

Категорія оцінки, як відомо, мотивована як об'єктивними, так і суб'єктивними чинниками. Ураховуючи це, лінгвісти виокремлюють відповідні типи об'єктивних та суб'єктивних оцінок. Серед суб'єктивних оцінок зазвичай виділяють емоційні чи модальні ${ }^{10} 11$. Загальновідомо, що емоція передбачає оцінку, проте оцінка може бути й суто раціональною. Визнається як аксіома те, що емоційний, емотивний компонент мовлення тісно пов'язаний з оцінкою, $є$ іiї складником. Нейтральних емоцій просто не буває. 3 огляду на філософію, психологію, релігієзнавство, негативні емоції шкідливі для фізичного і психічного здоров'я людини. Щоб запобігти цьому, як уважають психологи, необхідно вміти їх нейтралізувати, вміти їх позбуватися.

У вітчизняних та зарубіжних дослідженнях із психології існують різні думки щодо тлумачення категорії емоцій. Американський психолог К. Ізард схиляється до думки, що „емоції утворюють первинну мотиваційну систему людини”"2, а німецький психолог В. Вундт виділив тривимірний простір емоцій: „задоволення - незадоволення, збудження - спокій, напруження - розрядка" ${ }^{3}$.

Отже, беззаперечним $є$ факт, що емоція передбачає оцінку, а оцінка натомість $є$ одним з основних змістових компонентів смислу висловлювання, тексту чи дискурсу, передусім художнього.

В арсеналі комунікативних мовних засобів українців, як і росіян, містяться, на щастя, й такі мовні засоби, що зреалізовують збудження, обурення, незадоволення, але їхнє використання приводить людину в стан рівноваги, спо-

\footnotetext{
${ }^{2}$ В. Гум больдт, Избр. тр. по языковед., Москва 1984, с. 305.

${ }^{3}$ См.: Ш. Ба л л и, Общая лингвистика и вопросы франиузкого язика, Москва 1955.

${ }^{4}$ См..: А. Потебня, Тр. по языкозн., Москва 1996, с. 313.

${ }_{5}^{5}$ См.: В. А. Масло в а, Лингвокультурология, Москва 2001.

${ }^{6}$ См.: В. И. Караси к, Лингвокультурный типаж “английский чудак”, Москва 2006.

${ }^{7}$ Г. Ю. Богданович, указ. источ.

${ }^{8}$ Там же, с. 30.

${ }^{9}$ В . Д. С ліпе цька, Прокляття як засіб репрезентащй негативної комунікації, Харків

${ }^{10}$ Див.: Т. Кос меда, Аксіологічні аспекти прагмалінгвістики, Львів 2000.

${ }_{11}$ Див.: І.Ю.Шкіцька, Маніпулятивні тактики позитиву: лінгвістичний аспект, Тер-

${ }_{12}^{12}$. Д. С ліпецька, зазнач. джер.

${ }^{13}$ Див.: Г. С. Кир и ле н ко, Психологія: емоџійна сфера особистості, Київ 2007.
} 2011, c. 236-241. нопіль 2012 
кою, може спочатку загострити, але згодом нейтралізувати конфлікт, вияв надмірних емоцій гніву, люті, ненависті і под. Саме до таких мовних засобів відносимо прокляття. Якщо розглядати статус прокляття як мовної одиниці з огляду на граматичні категоріальні ознаки, то ці одиниці науковці слушно відносять до вигуків, інтер'єктивів ${ }^{14}$, що їх призначенням і $є$ вияв емоцій.

Загальновідомим є й той факт, що людина частіше переживає негативні емоції, і мовних засобів для вираження негативної оцінки і негативних емоцій у кожній мові існує більше. Українці й росіяни здавна для цього використовували прокляття, актуалізуючи їх зокрема й під час сварки, що давало змогу зняти накопичення негативної енергії, запобігти стресу, вияву агресії.

У Кайдашевій сім'ї І. Нечуй-Левицького знаходимо такі приклади використання проклять під час сварки:

1) - „Це ви, мабуть, з матір'ю так міряли город, бодай вас міряв сей та той!" - крикнула Мотря на порозі так, що двері з обох хат разом одчинились $i$ з дверей повискакували всі: і Карпо, й Лаврін, і Кайдашиха, й Мелашка. Вони повитріщали очі на Мотрю ${ }^{15}$;

2) - „Бий тебе сила Божа! Не кидай, бо я тобі голову провалю кочергою," - крикнула Кайдашиха й погналась за Мотрею. Мотря втекла за причілок, виглядала з-за вугла й репетувала та кляла Кайдашиху"б;

3) — „А бодай ці Западинці були запались, ніжс мала я в них їхати!”лаялась Кайдашиха, витягаючи сіно з-за пазухи, висмикуючи його з голови. „Оце заквітчалась сіном, як вівия реп'яхами: каторжне сіно коле в спину, хоч спідницю скидай!" "17;

4) - „А хіба ж ти не міряла сіней мотузком, як мазала діл та стіни?" - обізвалась Кайдашиха. — „Мірясте ви, бодай: вже міряла вас лиха година!" - обізвалась Мотря ${ }^{18}$.

У тексті Піквікського клубу англійського письменника Ч. Діккенса та в художньому творі М. Гоголя Как поссорились Иван Иваныч с Иваном Никифоровичем знаходимо приклади проклять:

1) — „Damn that boy!” - thought Mr. Wardle to himself. „Damn that boy! He must have been asleep" $" 19$;

2) — „Как! Дворянина?” - закричал с чувством достоинства и негодования Иван Иванович. — „, Осмельтесь только! Подступите! Я вас уничтожу с глупым вашим паном! Ворон не найдет места вашего!” (Иван Иванович говорил необыкновенно сильно, когда душа его бывала потрясена $)^{20}$.

Під час сварки, що переростає в бійку, омовлюються й невербальні засоби вираження негативних емоцій, що практично однаково репрезентуються в російській та українській мовах, зокрема підвищення тону голосу:

1) — „То ти через свою дурну жінку будеш мені цвікати таке в вічі! Чого ти, бісова дочко, гризешся з матір 'ю?" - крикнув старий Кайдаш, махаючи поламаним мотовилом. — „Чи ти хочеш бути найстаршою в хаті, чи щзо? Чи

${ }^{14}$ Л. М а ц ко, Інтер'єктиви в украйнській мові, Київ 2009, с. 453-518.

15 I. Нечуй - Ле в и ць к й й, Кайдашева сім'я, [в:] Електронний ресурс: http://www.ukrlib. com.ua/books/printthebook.php?id=74\&bookid=5\&part=5 (25.02.2017).

${ }^{16}$ Там само.

${ }^{17}$ Там само.

${ }^{18}$ Там само.

${ }^{19} \mathrm{Ch}$. Dickens, The Pickwik Papers, London 2011.

${ }^{20}$ Николай Гоголь, Как поссорились Иван Иваныч с Иваном Никифоровичем, [в:] Электронный ресурс: http://www.klassika.ru/read.html?proza/gogol/ssora.txt\&page=9] (25.02.2017). 
Засоби вираження негативних емочій під час сварки

в украӥнській, російській, англійській лінгвокультурах

ти хочеш, щоб мати була тобі за наймичку? Я тобі полічу ребра оцим мотовилом." Кайдаш махнув на Мотрю мотовилом $і$ зачепив ї̈ по ручі ${ }^{21}$;

2) — „Не лізь, бо задушу, іродова душе!”- - крикнув Карпо та й кинувся, неначе звір, на батька й штовхнув його обома кулаками в груди ${ }^{22}$.

3) — „Stay Mr. Jingle!” — said the spinster aunt emphatically. ,, You have made an allusion to Mr. Tupman - explain it.";

— „Never!”- - explained Jingle with a professional air. ,Never!” ${ }^{23}$;

4) — „Let me get at him, Pickwick,”—cried Wardle. ,Let me get at him!'”;

— „Don't let him!”- - screamed all the women.

— „I won't be held!” — cried the old man. „Mr. Winkle, take your hands off. Mr. Pickwick, let me go, sir!", ${ }^{24}$;

5) — „Sir!”- exclaimed Mr. Winkle, starting from the chair.

— „Serpent, sir!” - repeated Mr. Pott, raising his voice and then suddenly depressing it.

"I said serpent, sir — make the most of it" 25 ;

6) — „Beg your pardon, sir,” — said Wilkins, — „But — But what? Eh”? roared $h e^{26}$

7) — „Что вы такое сказали, Иван Никифорович?” - спросил он, возвысив голос ${ }^{27}$;

8) — „Как! Дворянина?”-закричал с чувством достоинства и негодования Иван Иванович ${ }^{28}$.

Об'єктом негативної оцінки може бути будь-який предмет чи особа як джерело виникнення в мовця негативних емоцій, що засвідчує факт використання не лише оцінювальних слів, але й слів-оцінок, напр.: боягуз (a coward), зрадник (a traitor), обманщик (a deceiver), брехун (a liar), негідник (a rascal), божевільний (mad), розбійник (a ruffian) в англійській лігвокультурі; дурак та назви тварин $з$ негативною конотацією: гусак, змія в українській, російській лінгвокультурах, наприклад:

1) — ,, Sir!" - said the doctor in an awful voice, producing a card, ,, my name is Slammer, Doctor Slammer - my card, sir, my card. "He would have added more, but his indignation choked him.

— „Ah!” - replied the stranger coolly.

— „You — you are a shuffler, sir!” — gasped the furious doctor. ,A poltroona coward - a liar! "'29;

2) — „You - you are a nice rascal, aren't you?" - exclaimed Wardle, breathless with passion ${ }^{30}$

3) — „You are mad," — said Mr. Pickwick.

— „Come on"! - said the cab-driver ${ }^{31}$;

4) - „Men are such deceivers, "- she softly whispered.

\footnotetext{
21 I. Нечуй - Лев ицьки й, зазнач. джер.

${ }^{22}$ Там само.

${ }^{23} \mathrm{Ch}$. Dickens, Ibidem, p. 133.

${ }^{24}$ Ibidem, p. 138.

${ }^{25} \mathrm{Ibide}$, p. 270.

${ }^{26}$ Ibidem, p. 293.

${ }^{27}$ Николай Гоголь, указ. источ.

${ }^{28}$ Там же.

${ }^{29} \mathrm{Ch}$. Dickens, ibidem, p. 45.

${ }^{30} \mathrm{Ibidem}$, p. 156.

${ }^{31}$ Ibide m, p. 30.
} 
— „, They are, they are,” - ejaculated Mr. Tupman. „But not all men. There lives at least one being who can never change",32;

5) — „Who is he, you scoundrel!" — interposed Wardle 33 ;

6) - „And I have only to add, sir, said Mr. Pickwick, now thoroughly angry, that I consider you a rascal and a - a ruffian - and - and worse than one man I ever saw or heard of except that pious and sanctified vagabond in the mulberry livery" 34 ;

7) — „Traitor!” - thought the spinster aunt. „Dear Mr. Jingle was not deceiving me. Ugh! How I hate the wretch!" ${ }^{35}$;

8) - „Как же вы смели, сударь, позабыв и приличие и уважение к чину и фамилии человека, обесчестить таким поносным именем?"”б;

9) — „Я повторяю, как вы осмелились, в противность всех приличий, назвать меня гусаком" 37

10) — „Мне странно, Иван Иванович: вы, кажется, человек, известный ученостью, а говорите, как недоросль. Что бы я за дурак такой ... "з8;

11) — „Ти — змія люта, а не свекруха!” — кричала Мотря. — „Буду я чортова дочка, коли не розіб'ю тобі кочергою голови"з .

Напевно, краще репрезентувати словесну погрозу, вихлюпнувши в такий спосіб негативні емоції, але відповідної дії не вчинити. Очевидно, так зреалізовувалася мудрість наших предків. Вони вміли нейтралізувати негативні емоції, стрес, агресію словесно.

Виявом негативної оцінки як наслідку негативних емоцій під час сварки, суперечки в досліджуваних лінгвокультурах є використання слів, що йменують нечисту силу як вияв найвищої негативної оцінки, зокрема це диявол, чорт, devil, наприклад:

1) - „Я вам дам за него бурую свинью, ту самую, что я откормил в сажу. Славная свинья! Увидите, если на следующий год она не наведет вам поросят."

— „Я не знаю, как вы, Иван Иванович, можете это говорить, на что мне свинья вама? Разве черту поминки делать."

— „Опять! без черта-таки нельзя обойтись! Грех вам, ей-богу, грех, Иван Никифорович!"

— „Как же вы, в самом деле, Иван Иванович, даете за ружье черт знает что такое: свинью!"”

— „Отчего же она - черт знает что такое, Иван Никифорович?”

— „Как же, вы бы сами посудили хорошенько. Это-таки ружье, вещьь известная; а то - иерт знает что такое: свинья! Если бы вы не говорили, я бы мог это принять в обидную для себя сторону" 40 ;

2 ) — „Who the devil are you?" - inquired Mr. Jingle in so fierce tone ${ }^{4 l}$;

3) — „А чом же ти мене не кидала, коли тобі було в мене погано?” - пищала Кайдашиха.

— „Чом тебе чорти не понесли на Бассарабію або заграницњю?” ${ }^{42}$.

\footnotetext{
${ }^{32} \mathrm{Ib}$ idem, p. 124.

${ }^{33} \mathrm{Ibidem}$, p. 156.

${ }^{34} \mathrm{Ibidem}$, p. 394.

${ }^{35}$ Ibidem, p. 135.

${ }^{36}$ Николай Гоголь, указ. источ.

${ }^{37}$ Там же.

${ }^{38}$ Там же.

39 I. Нечуй - Ле в иць к й й зазнач. джер.

${ }^{40}$ Николай Гоголь, указ. источ.

${ }^{41} \mathrm{Ch}$. Dickens, ibidem, p. 156.

${ }^{42}$ Ни иколай Гоголь, указ. источ.
} 
Засоби вираження негативних емоџій під час сварки

Викладені спостереження свідчать, що прокляття, слова-оцінки, які активно використовувалися в мовленні українців, росіян, англійців, $є$ виразними мовними засобами репрезентації негативної оцінки, вони дають змогу нейтралізувати вияв незадоволення, обурення, гніву, люті, агресії, тобто негативних емоцій під час сварки, суперечки. 